\title{
Kohesi dan Koherensi Ragam Bahasa Percakapan Masyarakat Pendatang di Daerah Pangandaran Kabupaten Ciamis
}

\author{
Nurfathana Mazhud ${ }^{1}$ \\ ${ }^{1}$ Universitas Muslim Indonesia, Makassar \\ 1nurfathana.mazhud@umi.ac.id
}

\begin{abstract}
The Pangandaran area has become a prime tourist attraction in West Java, said to have been quite well known since the Dutch colonial era. This becomes the rationale for doing this research. The objectives of this study are (1) to find out the dominant conversation language used; (2) to determine the correct pronunciation in the use of Sundanese vocabulary; and (3) to find out the factors that cause the emergence of various languages. This type of study is a survey research design which is used to obtain and collect data or information about the object of research, namely conversation. Based on the description of the results of research and discussion, it can be concluded as follows: (1) The languages used are: Sundanese, Javanese, Indonesian, and those that sometimes use English if foreign tourists visiting there do not know Indonesian; (2) In terms of discourse cohesion shows that in the data there are cohesion markers used by speakers in the conversation, both reduplication and conjunction forms used in sentences spoken and used in the same atmosphere and place; and (3) In terms of discourse coherence in every conversation analysis that has been done shows that not all conversations show the coherence of a discourse, but there are also conversations that do not show coherence due to the number of speakers so that the emergence of new topics in the conversation is difficult to avoid.
\end{abstract}

Keywords: cohesion, coherence, and language variety

Abstrak: Daerah Pangandaran menjadi objek wisata primadona Jawa Barat, konon sudah cukup terkenal sejak zaman penjajahan Belanda. Hal inilah yang menjadi alasan untuk melakukan penelitian. Adapun tujuan penelitian yakni (1) untuk mengetahui bahasa percakapan yang lebih dominan digunakan; (2) untuk mengetahui ketepatan pelafalan dalam penggunaan kosakata bahasa Sunda; dan (3) untuk mengetahui faktor penyebab munculnya ragam bahasa. Jenis penelitian yang dilakukan adalah penelitian survei. Survei digunakan untuk memperoleh dan mengumpulkan data atau informasi tentang objek penelitian yaitu percakapan. Berdasarkan uraian hasil penelitian dan pembahasan maka dapat disimpulkan sebagai berikut: (1) Bahasa yang digunakan yaitu: bahasa Sunda, bahasa Jawa, bahasa Indonesia, dan adapula yang kadang menggunakan bahasa Inggris jika wisatawan mancanegara yang berkunjung ke sana tidak mengetahui bahasa Indonesia; (2) Dari segi kohesi wacana menunjukkan bahwa dalam data tersebut terdapat pemarkah kohesi yang digunakan oleh penutur dalam percakapan, baik bentuk reduplikasi maupun konjungsi yang digunakan dalam kalimat yang dituturkan dan digunakan dalam suasana dan tempat yang sama; dan (3) Dari segi koherensi wacana dalam setiap analisis percakapan yang telah dilakukan menunjukkan bahwa tidak semua percakapan menunjukkan koherensi suatu wacana,

Sitasi Artikel:

Mazhud, N. (2020). Kohesi dan Koherensi Ragam Bahasa Percakapan Masyarakat Pendatang di Daerah Pangandaran Kabupaten Ciamis. Disastra: Jurnal Pendidikan Bahasa dan Sastra Indonesia, 2(2), 182-191. doi:http://dx.doi.org/10.29300/disastra.v2i2.3065 
namun terdapat pula percakapan yang tidak menunjukkan koherensi disebabkan karena banyaknya penutur sehingga munculnya topik baru dalam percakapan tersebut sulit untuk dihindari.

Kata Kunci: kohesi, koherensi, ragam bahasa

\section{Pendahuluan}

Setiawati (2019:4), "variasi
bahasa merupakan cermin tidak seragamnya para pengguna bahasa, keragaman bahasa yang penggunaannya disesuaikan dengan situasi dan fungsi yang berlaku". Selain itu, Penalosa (1981: 30) mengemukakan bahwa "adanya suatu perubahan baik linguistik dan sosiolinguistik merupakan perubahan yang terjadi dalam bahasa tunggal atau perubahan dalam ragam bahasa yang digunakan untuk maksud yang berbeda." Biasanya perubahan linguistik jauh lebih lambat dari perubahan sosial, meskipun kita hanya bisa berbicara tentang perubahan yang relatif cepat atau relatif lambat dalam kedua kasus perubahan linguistik maupun perubahan sosial tersebut.

Berkaitan dengan keragaman bahasa membawa nilai-nilai sosial, sehingga proses penerimaan dan penolakan berlangsung di lingkungan masyarakat, baik pada masyarakat yang homogen maupun masyarakat heterogen. Dengan demikian, penggabungan bahasa bergantung pada faktor-faktor yang terkait dengan gengsi/wibawa, yang pada gilirannya terkait dengan usia, geografi, dan etnis. Dari berbagai kemungkinan yang terjadi baik perubahan linguistik maupun perubahan sosial menjadi landasan untuk mengetahui penggunaan ragam bahasa percakapan bagi masyarakat Pangandaran. Dalam kesehariannya, masyarakat berkomunikasi dengan menggunakan tuturan yang khas dalam setiap interaksi tertentu dengan masyarakat lainnya.

Penggunaan ragam bahasa yang baik ditandai dengan adanya hubungan kooperatif yang disebut kohesi dan koherensi sehingga tidak menimbulkan persepsi yang ambigu. "Sebuah wacana disebut baik apabila wacana itu kohesif dan koherensi. Untuk membuat wacana yang kohesif dan koheren itu dapat digunakan berbagai alat wacana, baik yang berupa aspek gramatikal maupun yang berupa aspek leksikal, atau gabungan antar kedua aspek itu" (Goziyah \& Harninda, 2018: 139). Menurut Zaimar dan Harahap (2015) "Kohesi adalah keterkaitan unsur-unsur lahiriah suatu teks." Selain kohesi, sebuah percakapan harus memiliki unsur koherensi yakni hubungan pemaknaan. Widiatmoko (2015) melakukan penelitian juga dan menemukan bahwa koherensi yang terdapat dalam Majalah daring "Detik" mencakup hubungan perbandingan, hubungan kelonggaranhasil, hubungan akibat-sebab, hubungan sebab-akibat, hubungan makna alasan (argumentatif), dan hubungan latarsimpulan. Dalam penelitian tersebut juga ditemukan bahwa kepaduan yang paling banyak digunakan adalah kohesi gramatikal berupa pengacuan dan konjungsi.

Pantai Pangandaran terletak di Kabupaten Ciamis. Ciamis merupakan salah satu kabupaten yang ada di Provinsi Jawa Barat. Di sana, tepatnya di Desa Pananjung, Kecamatan Pangandaran, 
sekitar 92 kilometer arah selatan Kota Ciamis ada sebuah pantai yang bernama Pangandaran. Pantai yang menjadi objek wisata primadona Jawa Barat ini konon sudah cukup terkenal sejak zaman penjajahan Belanda. Hal inilah yang menjadi alasan untuk melakukan penelitian dengan tujuan mengetahui penggunaan ragam bahasa bagi masyarakat Pangandaran. Masyarakat Pangandaran yang berasal dari berbagai wilayah juga menjadi alasan untuk mengetahui penggunaan ragam bahasanya. Selain itu, banyak wisatawan yang berkunjung ke sana baik wisatawan domestik maupun wisatawan mancanegara dengan keragaman bahasa yang digunakan dalam berkomunikasi.

Adapun tujuan penelitian, yakni: (1) untuk mengetahui bahasa percakapan yang digunakan masyarakat Pangandaran dalam berkomunikasi ditinjau dari bentuk data dan data sebenarnya; (2) untuk mengetahui bahasa percakapan yang digunakan masyarakat Pangandaran ditinjau dari segi kohesi wacana; dan (3) untuk mengetahui bahasa percakapan yang digunakan masyarakat Pangandaran ditinjau dari segi koherensi wacana.

\section{Sosiolinguistik}

merupakan

"Kajian yang bersifat interdisipliner yang mengkaji masalah-masalah kebahasaan dalam hubungannya dengan aspek-aspek sosial, situasional, dan budaya (culture). Oleh sebab itu apabila seseorang berbicara dengan orang lain di samping masalah kebahasaan itu sendiri, maka harus diperhatikan orang lain juga. Dengan memperhatikan sosiolinguistik, masalah ketidaktepatan pemakaian bahasa dalam konteks sosialnya dapat diminimalkan. Dengan memahami prinsip-prinsip sosiolinguistik setiap penutur akan menyadari betapa pentingnya ketepatan pemilihan variasi bahasa sesuai dengan konteks sosial, di samping kebenaran secara struktural gramatikal" (Abdurrahman, 2011: 23). Jadi, variasi bahasa adalah sejenis ragam bahasa yang pemakaiannya disesuaikan dengan fungsi dan situasinya, tanpa mengabaikan kaidah-kaidah pokok yang berlaku dalam bahasa yang bersangkutan. Hal ini dikarenakan, variasi bahasa itu terjadi sebagai akibat dari adanya keragaman sosial dan keragaman fungsi bahasa.

Setiap perbuatan bisa di tafsirkan sesuai dengan kebiasaan budaya dalam suatu masyarakat. Suatu perbuatan bisa disebut bersifat komunikatif adalah kala perbuatan itu dilakukan dengan sadar dan ada pihak lain yang bertindak sebagai penerima pesan dari perbuatan itu. Dalam setiap komunikasi ada dua pihak yang terlihat, yaitu pengirim pesan (sender), penerima pesan (receiver). Setiap proses komunikasi bahasa dimulai dengan si pengirim merumuskan terlebih dahulu apa yang akan diujarakan dalam bentuk suatu gagasan. Chaer (2004: 62) mengatakan bahwa variasi bahasa itu pertama-tama kita bedakan berdasarkan penutur dan penggunanya. Adapun penjelasan variasi bahasa yang disesuaikan objek penelitian yaitu variasi bahasa dari segi penutur. Variasi bahasa dari segi penutur adalah variasi bahasa yang bersifat individu dan variasi bahasa dari sekelompok individu yang jumlahnya relatif, yang berada pada satu tempat/wilayah atau area. 
Seperti yang telah dipaparkan sebelumnya, terdapat dua unsur pembentuk wacana yang menjadi perhatian utama. Kedua unsur tersebut adalah kohesi dan koherensi. Kohesi pada dasarnya berkaitan erat dengan aspek semantis antar unsur di dalam teks. Halliday dan Hasan (1976) membagi kohesi ke dalam lima jenis. Kelima jenis tersebut adalah (1) substitusi, yaitu penyulihan suatu kata atau kelompok kata oleh kata lain untuk tujuan tertentu; (2) referensi, yaitu hubungan pengacuan suatu unsur dengan unsur lain baik yang muncul sebelumnya, sesudahnya, atau bahkan di luar teks; (3) elipsis, yaitu pelesapan suatu kata atau bagian dari kalimat yang dilakukan untuk kepaduan wacana; (4) konjungsi; yaitu hubungan yang mengindikasikan bagaimana sebuah kalimat atau klausa dihubungkan dengan kalimat atau klausa lain; dan (5) kohesi leksikal, yaitu hubungan semantis antarunsur pembentuk wacana dengan memanfaatkan unsur leksikal atau kata.

Kepaduan suatu wacana tidak hanya ditentukan oleh kehadiran pemarkah kohesi yang mengacu pada perangkat formal sebuah teks, seperti yang telah dipaparkan sebelumnya. Kepaduan suatu wacana dapat pula ditunjukkan oleh perangkat kontekstual suatu teks, yang berupa situasi yang melatarbelakangi teks sehingga teks tersebut dapat dipahami sebagai wacana yang padu (Paltridge, 2006: 139).

\section{Metode Penelitian}

Jenis penelitian yang dilakukan adalah penelitian survei. Survei digunakan untuk memperoleh dan mengumpulkan data atau informasi tentang objek penelitian yaitu percakapan. Dengan jumlah penduduk yang sangat banyak sebagai populasi penelitian, sehingga penarikan sampel diambil yaitu beberapa masyarakat Pangandaran dengan jumlah relatif sedikit dengan waktu yang relatif singkat.

Data diperoleh melalui observasi (untuk mengamati secara langsung percakapan yang dilakukan oleh masyarakat dalam berkomunikasi dengan masyarakat lainnya), studi dokumentasi, dan wawancara terhadap suatu komunitas masyarakat yang ada di daerah Pangandaran. Sumber data lisan adalah informan yang merupakan masyarakat yang ada di wilayah Pangandaran.

Metode yang digunakan adalah metode survei deskriptif. Metode survei deskriptif adalah suatu metode penelitian yang mengambil sampel dari suatu populasi. Setelah data diperoleh, kemudian hasilnya akan dipaparkan secara deskriptif.

Hal yang utama dalam pengumpulan data adalah mengetahui secara jelas atau identifikasi lokasi penelitian dan masyarakat yang siap atau bersedia untuk dijadikan objek penelitian dan memiliki kriteria yang sesuai dengan fokus utama dalam penelitian. Setelah itu, jenis-jenis data yang akan dikumpulkan melibatkan tiga strategi yakni (1) observasi dilakukan peneliti secara langsung turun ke lapangan untuk mengamati percakapan bagi masyarakat yang sedang melakukan komunikasi. Data observasi dapat pula diperoleh dengan merekam percakapan tersebut atau mencatat hal-hal yang dianggap penting; 
(2) peneliti melakukan wawancara secara langsung kepada warga masyarakat yang bersedia untuk dijadikan partisipan. Wawancara tersebut berupa pertanyaanpertanyaan yang tidak terstruktur dan bersifat terbuka. Peneliti menyiapkan format pertanyaan yang berkaitan dengan hal yang akan diteliti untuk memunculkan pandangan dan opini dari para partisipan mengenai bahasa percakapan digunakan dalam berkomunikasi; dan (3) dokumentasi diperoleh saat proses observasi dan wawancara yang dilakukan saat penelitian berupa foto dan hasil rekaman percakapan masyarakat pendatang.

Data yang telah dikumpulkan dianalisis secara keseluruhan dengan memperdalam pemahaman akan data tersebut, menyajikan data, yang membuat interpretasi makna yang lebih luas mengenai penggunaan ragam bahasa percakapan bagi masyarakat khususnya masyarakat yang berada di daerah Pangandaran. Adapun langkah-langkah yakni (1) Identifikasi data, data yang diperoleh dari lapangan berupa hasil rekaman tuturan (percakapan) responden diubah menjadi bentuk tulisan atau transkripsi data. Setelah itu, data diidentifikasi sesuai kebutuhan berkaitan dengan analisis yang akan dilakukan; (2) Analisis data, data yang dianalisis adalah percakapan yang telah ditranskripsi. Analisis yang dilakukan peneliti adalah membandingkan, mengulas, dan mendeskripsikan disesuaikan dengan analisis wacana ditinjau dari segi kohesi dan koherensi; (3) Hasil Analisis Data, hasil analisis data berupa data kualitatif yaitu berupa frasa ataupun kalimat yang dianalisis dari segi kohesi dan koherensi suatu wacana untuk mengetahui penggunaan bahasa percakapan yang digunakan masyarakat Pangandaran; dan (4) Pembahasan analisis data, hasil analisis data dibahas dengan mendeskripsikan hasil analisis dari segi kohesi dan koherensi yang terdapat dalam hasil transkripsi data. Selanjutnya, disusun kesimpulan yang diambil dari hasil analisis data.

\section{Hasil dan Pembahasan}

Setelah data yang ada ditranskripsikan, selanjutnya dianalisis percakapan tersebut ditinjau dari segi kohesi dan koherensi wacana. Adapun hasil analisis sebagai berikut.

\section{Rekaman 1}

Pada hasil transkripsi data yang pertama yang dilakukan di pinggiran jalan (pertigaan jalan) dengan melakukan percakapan pada seorang penjual bakso yang berusia sekitar 40 tahun. Penjual bakso tersebut seorang laki-laki yang berasal dari kabupaten Banjar tetapi sudah lama menetap di Pangandaran. Bapak tersebut sudah puluhan tahun berjualan di Pangandaran yang awalnya hanya ikut dengan orang tua yang berjualan baksi hingga pada akhirnya membuka usaha sendiri.

Saya dan seorang teman secara sengaja membeli bakso dan makan di pinggiran jalan tersebut sambil bercerita dengan Bapak Penjual Bakso. Adapun kutipan percakapan tersebut:

Penutur I : ya, itukan pengaruhnya kenapa? Pengaruh ini kan, pengaruh panas. 
Lautkan panas, terus cuaca panas, jadi suara harus keras atau tinggi. Hanya kalau berjual beli atau apalah, juga bahasanya ae... oe...

Penutur II: Oe... (dengan memberikan contoh dengan nada tinggi atau terkesan berteriak) kayak di gunung.

Penutur III: Tapi orang yang asli Pangandaran yang mana?Kan tadi Bapak mengatakan orang Pangandaran kalau ada masalah...

Penutur II : anak-anak pantai itu...

Dari kutipan percakapan di atas dapat diketahui bahwa terdapat pemarkah kohesi yaitu kata 'atau' (R1, T1) yang merupakan konjungsi antar kalimat. Selain itu, terdapat pula pengulangan kata 'anak-anak' (R1, T4) yang merupakan reduplikasi gramatikal yang ditandai dengan perubahan makna antar kata 'anak' yang berarti seorang anak dan kata 'anak-anak' yang berarti lebih dari satu.

Koherensi antar kalimat dari kutipan percakapan di atas sebagai pembaca kiranya dapat memahami percakapan di atas, yaitu ketika penutur I menginformasikan kepada II bahwa suhu daerah pantai itu panas, penutur II merespon dengan menuturkan ujaran 'oe...' secara refleks dilakukan menunjukkan bahwa suara masyarakat pesisir pantai umumnya bersuara besar. Secara gramatikal sama sekali tidak tampak adanya relasi antara ujaran I dan II. Akan tetapi, ketika dihubungkan dengan konteks di luar teks, yaitu kegiatan penutur II yang memberikan contoh kepada penutur I dapat memahami. Pada dasarnya kedua partisipan tersebut dapat saling memahami karena mereka yang melakukan percakapan tersebut. Oleh karena itu, dapat dikatakan bahwa percakapan di atas merupakan wacana yang koheren.

\section{Rekaman 2}

Data kedua diperoleh saat melakukan percakapan dengan dua orang suami istri yang berdagang pakaian di sekitar pesisir pantai. Salah satu teman yang kebetulan melihat model pakaian yang katanya unik dan cocok untuk anaknya mengajak untuk singgah melihat pakaian tersebut dan secara tidak langsung kami merekam percakapan saat berkomunikasi dengan pedagang tersebut.

Adapun kutipan percakapan tersebut:

Penutur I : iya, biasanya itu ada teman yang mau ke sini minta dicarikan tempat dulu, jadi pas tiba di sini bisa langsung.

Penutur III : di sekitaran sini nih ada banyak penginapan yang murah-murah.

Penutur I : kan si ibunya juga bilang baru sekitaran 6 bulan di sini berdagangnya...

Penutur III : iya, tapi sudah lama di sini, kan suami orang sini jadi sudah tinggal sekitar 2 tahun...

Dari kutipan percakapan di atas dapat diketahui bahwa terdapat pemarkah kohesi yaitu reduplikasi kata 'murahmurah' (R2, T16) yang merupakan reduplikasi gramatikal yang ditandai dengan perubahan makna antar kata 'murah' yang berarti lebih rendah dari pada harga yang dianggap berlaku di pasaran dan kata 'murah-murah' yang 
berarti banyak yang murah. Terdapat pula pelesapan suatu kata atau bagian dari kalimat yang dilakukan untuk kepaduan wacana pada frasa 'di sekitaran sini nih' yang semestinya 'di sekitar pesisir Pangandaran ini' tetapi penutur sebelumnya memahami konteks pembicaraan sehingga dilakukan pelesapan frasa. Selain itu, terdapat pila pemarkah kohesi yaitu konjungsi yang berupa kata 'tapi' seperti pada data rekaman 1.

Koherensi antar kalimat dari kutipan percakapan di atas sebagai pembaca kiranya dapat memahami percakapan di atas, yaitu ketika penutur I menginformasikan kepada penutur III bahwa temannya yang biasa datang berkunjung ke Pangandaran terlebih dahulu menghubunginya untuk mencarikan penginapan sebelum berangkat, penutur III merespon dengan menambahkan tuturan sebagai penambah keterangan ujaran bahwa banyak penginapan di sekitar sini yang lebih murah sambil menunjuk ke arah beberapa hotel yang dekat dari pesisir pantai saat melakukan percakapan. Secara gramatikal tampak adanya relasi antara ujaran I dan III dan ketika dihubungkan dengan konteks di luar teks, yaitu dengan penutur yang lain saling berkaitan. Oleh karena itu, dapat dikatakan bahwa percakapan di atas merupakan wacana yang koheren.

\section{Rekaman 3}

Data hasil penelitian yang ketiga diperoleh saat berada di pinggir pantai dengan tujuan untuk pergi ke pasir putih dengan cara naik perahu penyeberangan dengan teman-teman yang lain, tetapi beberapa dari teman ada yang mengerti bahasa Sunda dan bahasa Jawa sehingga di sela-sela percakapan mereka menggunakan beberapa bahasa dalam waktu yang bersamaan. Percakapan teman-teman dengan pengemudi perahu penyeberangan berlangsung agak lama mulai dari penawaran harga penyewaan perahu hingga menanyakan lebih jauh mengenai bahasa yang dipahami serta asal daerah sebelum mereka menemukan kesepakatan untuk ke pantai Pasir Putih pada sore hari saja.

tersebut:

Adapun kutipan percakapan

Penutur IV : Heemmm, ket kapan kerjo teng nggenne mriki?

Penutur II : 2004, ya Tsunami yang Pangandaran, $\mathrm{Bu}$.

Penutur III : Sa'derenge teng pundi?

Penutur II : Teng ngenne hotel.

Penutur III : Teng mriki rame, Mas?

Dari kutipan percakapan di atas yang menggunakan bahasa daerah mengenai pembicaraan antara penutur II, III, dan IV. Koherensi antar kalimat dari kutipan percakapan di atas sebagai pembaca kiranya kurang memahami percakapan di atas, yaitu ketika penutur IV menanyakan berapa lama penutur II bekerja sebagai pengemudi perahu penyeberangan, lalu menjawab bahwa setelah Tsunami. Bagi masyarakat yang tidak mengetahui secara jelas Pantai Pangandaran pasti akan menimbulkan tanda tanya berapa lama dan apakah pernah terjadi tsunami? Setelah itu, tibatiba penutur III memunculkan permasalahan baru dengan menanyakan asal daerah kemudian bertanya lagi dengan topik yang berbeda atau kurang 
berkaitan dengan hal yang dituturkan sebelumnya. Secara gramatikal tidak tampak adanya relasi dan ketika dihubungkan dengan konteks di luar teks, yaitu dengan penutur yang lain tidak saling berkaitan. Oleh karena itu, dapat dikatakan bahwa percakapan di atas merupakan wacana yang tidak koheren.

\section{Pembahasan}

Masyarakat Pangandaran yang berasal dari berbagai suku dan juga merupakan daerah wisata yang cukup di kenal baik di dalam negeri maupun luar negeri. Hal ini memberikan pengaruh besar terhadap bahasa yang digunakan dalam berkomunikasi dengan masyarakat lainnya. Bahasa yang digunakan yaitu: bahasa Sunda, bahasa Jawa, bahasa Indonesia, dan adapula yang kadang menggunakan bahasa Inggris jika wisatawan mancanegara yang berkunjung ke sana tidak mengetahui bahasa Indonesia yang merupakan bahasa nasional Negara Kesatuan Republik Indonesia. Hal ini sejalan dengan pendapat Pangaribuan (2011) "Hubungan budaya dengan bahasa merupakan hubungan yang berlanjut secara terusmenerus. Struktur sosial menimbulkan ragam struktur bahasa atau ragam linguistik tertentu terutama dalam berperilaku. Perilaku tersebut pada gilirannya menghasilkan kembali struktur sosial yang baru. Hal ini akan berlanjut seperti lingkaran; pola sosial tertentu akan menghasilkan pola linguistik tertentu yang pada gilirannya menghasilkan kembali pola sosial dan seterusnya."

Demikian pula halnya dengan data yang telah dianalisis ditinjau dari segi kohesi wacana menunjukkan bahwa dalam data tersebut terdapat pemarkah kohesi yang digunakan oleh penutur dalam percakapan, baik dalam bentuk reduplikasi maupun konjungsi yang digunakan dalam kalimat yang dituturkan dan digunakan dalam suasana dan tempat yang sama. Sesuai dengan pendapat Aslinda (2007: 17) menyatakan bahwa variasi bahasa adalah bentuk-bentuk bagian atau varian dalam bahasa yang masing-masing memiliki pola yang menyerupai pola umum bahasa induknya. Variasi bahasa disebabkan oleh adanya kegiatan interaksi sosial yang dilakukan oleh masyarakat/kelompok yang sangat beragam dan dikarenakan oleh para penuturannya yang tidak bersifat homogen.

Dari segi koherensi wacana dalam setiap analisis percakapan yang telah dilakukan menunjukkan bahwa tidak semua percakapan menunjukkan koherensi suatu wacana, namun terdapat pula percakapan yang tidak menunjukkan koherensi disebabkan karena banyaknya penutur sehingga munculnya topik baru dalam percakapan tersebut sulit untuk dihindari. Kepaduan suatu wacana tidak hanya ditentukan oleh kehadiran pemarkah kohesi yang mengacu pada perangkat formal sebuah teks, seperti yang telah dipaparkan sebelumnya. Kepaduan suatu wacana dapat pula ditunjukkan oleh perangkat kontekstual suatu teks, yang berupa situasi yang melatarbelakangi teks sehingga teks tersebut dapat dipahami sebagai wacana yang padu (Paltridge, 2006: 139).

Secara umum fungsi bahasa adalah sebagai alat komunikasi baik 
secara lisan maupun tulisan. Suatu konteks dapat dipahami sebagai situasi yang selalu berubah, yang membuat masyarakat dalam proses komunikasi dapat berinteraksi dan dengan konteks pula ekspresi bahasa yang mereka gunakan dalam berinteraksi menjadi dapat dipahami. Dalam kaitannya dengan dunia pendidikan melibatkan segala aspek termasuk aspek sosial dan kebahasaan yang menjadi satu kesatuan sehingga mampu menyesuaikan dengan adatistiadat dan kebiasaan masyarakat dengan adanya suatu komunikasi. Selain itu, fungsi bahasa juga melambangkan pikiran atau gagasan tertentu, dan juga melambangkan perasaan, kemauan bahkan dapat melambangkan tingkah laku seseorang. Seperti yang dikemukakan oleh Wibowo (2001 : 3), "Bahasa di dalam wacana linguistik, diberi pengertian sebagai sistem simbol bunyi bermakna dan berartikulasi (dihasilkan oleh alat ucap), yang bersifat arbitrer dan konvensial, yang dipakai sebagai alat berkomunikasi oleh sekelompok manusia untuk melahirkan perasaan dan pikiran".

Dengan mengetahui bahwa dalam satu wilayah atau komunitas masyarakat tertentu yang menggunakan beberapa bahasa dalam berkomunikasi dengan masyarakat lain memberikan pemahaman baru bahwa pentingnya memahami beberapa bahasa dapat memudahkan kita berinteraksi dengan lingkungan sekitar. Misalnya saja, saat duduk di bangku sekolah dasar, selain bahasa Indonesia diajarkan bahasa daerah yang merupakan mata pelajaran muatan lokal bahkan telah diajarkan pula bahasa asing seperti bahasa Inggris. Penguasaan beberapa bahasa menjadi salah satu modal yang kuat untuk memudahkan seseorang dalam beradaptasi dengan lingkungannya. "Dalam penggunaan bahasa dapat diketahui bahwa ada hubungan antara struktur sosial tertentu dan cara masyarakat dalam menggunakan bahasa. Hubungan ini berlangsung terus-menerus dari suatu generasi ke generasi berikutnya yang mengarah pada pembentukan perilaku linguistik (Waridah, 2015:92).

\section{Simpulan}

Berdasarkan uraian hasil penelitian dan pembahasan maka dapat disimpulkan sebagai berikut.

1. Bahasa yang digunakan yaitu: bahasa Sunda, bahasa Jawa, bahasa Indonesia, dan adapula yang kadang menggunakan bahasa Inggris jika wisatawan mancanegara yang berkunjung ke sana tidak mengetahui bahasa Indonesia yang merupakan bahasa nasional Negara Kesatuan Republik Indonesia.

2. Dari segi kohesi wacana menunjukkan bahwa dalam data tersebut terdapat pemarkah kohesi yang digunakan oleh penutur dalam percakapan, baik dalam bentuk reduplikasi maupun konjungsi yang digunakan dalam kalimat yang dituturkan dan digunakan dalam suasana dan tempat yang sama.

3. Dari segi koherensi wacana dalam setiap analisis percakapan yang telah dilakukan menunjukkan bahwa tidak semua percakapan menunjukkan koherensi suatu wacana, namun terdapat pula percakapan yang tidak menunjukkan koherensi disebabkan 
karena banyaknya penutur sehingga munculnya topik baru dalam percakapan tersebut sulit untuk dihindari.

\section{Daftar Pustaka}

Abdurrahman. 2011. Sosiolinguistik: Teori, Peran, dan Fungsinya terhadap Kajian Bahasa Sastra.

Aslinda dan Leni Syafyahya. 2007. Pengantar Sosiolinguistik. Bandung: Refika Aditama.

Chaer, Abdul \& Leonie Agustina. 2004. Sosiolinguistik Perkenalan Awal. Jakarta: Rineka Cipta.

Halliday \& Hasan. 1976. Cohesion in English. London: Longman.

Goziyah \& Harninda. 2018. Kohesi dan Koherensi dalam Koran Bisnis Indonesia dengan Kudul KEMENPERIN Jamin Serap Garam Rakyat. Jurnal Penelitian Pendidikan Bahasa Indonesia, Daerah, dan Asing (SILAMPARAI BISA).

Pangaribuan, Tangson. 2011. Hubungan Variasi Bahasa dengan Kelompok Sosial dan Pemakaian Bahasa. Jurnal Bahasa Unimed.

Paltridge. 2006. Discourse Analysis: An Introduction. London: Continuum.

Penalosa. 1981. "Introduction to the Sociology of Language”.

Setiawati, Rias Dwi. 2019. Variasi Bahasa dalam Situasi tidak Formal pada Mahasiswa Program Studi Pendidikan Bahasa Indonesia di Universitas Tadulako. Jurnal Bahasa dan Sastra. Vol. 4, No. 1.
Yuliawati. Susi. 2008. Konsep Percakapan. http://intl.feedfury. 15241462-ragam-bahasa.html diakses tanggal 17 Desember 2018.

Waridah. 2015. Penggunaan Bahasa dan Variasi Bahasa dalam Berbahasa dan Berbudaya. Jurnal Simbolika. Vol. 1, No.1

Wibowo, Wahyu. 2001. Manajemen Bahasa: Pengorganisasian Karangan Pragmatik dalam Bahasa Indonesia untuk Mahasiswa dan Praktisi Bisnis. Jakarta: PT.Gramedia Pustaka Utama.

Widiatmoko. 2015. Analisis Kohesi dan Koherensi Wacana Berita Rubrik Nasional di Majalah Online Detik. Jurnal Sastra Indonesia.

Zaimar. Sumantri. Harahap. Ayu Basuki. 2015. Teori Wacana. Jakarta: Penaku. 